\title{
Buyer' Black Box Model Change in COVID-19 Pandemic
}

\author{
Daniel Hermawan
}

Parahyangan Catholic University, Jawa Barat 40141, Indonesia

\begin{abstract}
A B S T R A C T
The COVID-19 pandemic has changed the structure of human life globally, starting from the social, economic, political, health aspects, and so on. This study attempts to map the impact of changes in Generation $\mathrm{Z}$ consumer behavior in the period before and after the COVID-19 pandemic took place with the black box model in 3 stages, namely stimuli, transformers, and responses. The study was conducted on 186 undergraduate students with an age range of 17-24 years in measuring changes in 3 aspects, namely consumption patterns, entertainment, and basic necessities. The research model uses mixed methods with concurrent models, through the type of concurrent triangulation strategy. The results showed that there was a significant change in consumption and entertainment patterns in terms of the selection of purchasing methods and processes. Surprisingly, the pattern of shopping for basic necessities tends to not experience significant changes and contrasts with the media coverage of panic buying.
\end{abstract}

A R T I C L E I N F O

Article History:

Received : 04-12-2020

Revised : 02-03-2021

Accepted : 21-05-2021

Published : 30-06-2021

Keywords:

Black Box Model

Customer Behavior

COVID-19

Generation Z

Students

JEL: D120, M310, M370

*Corresponding Author E-mail:

daniel.hermawan@unpar.ac.id

Copyright (C) 2021 Authors. This is an open access article distributed under the Creative Commons Attribution License (CC-BY-SA 4.0) which permits use, distribution and reproduction in any medium, provided the original work is properly cited \& ShareAlike terms followed.

\section{INTRODUCTION}

The COVID-19 pandemic has changed the structure of human life globally, starting from the social, economic, political, health aspects, and so on (Al-Lamongani, 2020). The virus, thought to have originated from Wuhan, China, has spread to more than 200 countries around the world. It has infected more than 2.4 million people worldwide and more than 165,000 of them died (WorldoMeter, 2020). A number of countries impose lockdowns to prevent the spread of the COVID-19 virus, such as India, Italy, Spain, Denmark, Malaysia, New Zealand, the United Kingdom, and various other countries (Detikcom, 2020).

In anticipating the spread of the COVID-19 virus, there have been significant changes from the way humans interact, study, work, to shopping in various countries. In Indonesia, since the 
social/physical distribution policy was enacted, the \#StayAtHome (\#DiamdiRumah) campaign has begun to be promoted by various institutions, both from government agencies to private institutions (Kementrian PUPR, 2020). Along with the increase in casualties and the number of positive COVID-19 patients in Indonesia, now the adoption of Large Scale Social Restrictions (PSBB) and the determination of the COVID-19 virus as a non-natural national disaster requires the community to obey the rules to break the chain of COVID-19 distribution (Mashabi, 2020).

Beginning when news of a positive case of COVID19 was found in Indonesia, there was a panic buying phenomenon in several major cities in Indonesia, such as Jakarta, Bandung, Surabaya, and so on (Putri, 2020). Panic buying is caused by public concern about lockdown after news of COVID-19 positive victims in the media (CNN Indonesia, 2020). People queue to buy groceries, instant noodles, and various other food needs on a large scale, so it is feared to trigger an economic crisis due to food scarcity.

In addition, socially the spread of COVID-19 has also changed the overall economic map of the community. Integrated shopping centers or malls began to stop operations to support the government in carrying out physical distancing, as a result many tenants were forced to close in fulfilling the appeal (Helabumi, 2020). This has implications for layoffs that occur in some retail companies because they are unable to cover operational costs and salaries of employees after the COVID-19 pandemic due to a decrease in people's purchasing power, as well as the lack of income earned (CNN Indonesia, 2020).

The educational aspects have also changed drastically. Since the appeal issued for distance education by the Ministry of Education and Culture of the Republic of Indonesia, universities and schools have begun to tidy up to prepare material online (Kasih, 2020). Of course this sudden policy has caused surprises for universities and schools that are not ready in the aspect of digital infrastructure, so they must adapt to the various platforms available to fulfill their teaching and learning obligations (BBC Indonesia, 2020). Class meetings turn into virtual meetings in online meeting application forums, such as Google Hangouts Meet, Zoom, Cisco Webex, and so on.

Not to forget the social relations also changed with the advice of social distancing, namely starting from how to greet, communicate, to socialize. Various ways to greet others, such as shaking hands, shaking hands with elbows, until the 'virtual' greeting becomes a new type of social interaction that develops (BBC Indonesia, 2020). In addition, communication and interactions that were originally carried out in the coffee shop after work hours have returned to online communication with the application platform available with the emergence of various interesting challenges from social media, such as the challenge Until Tomorrow, BINGO, and various other challenges (Prasetya, 2020).

Seeing the phenomena that occur, this study aims to explore the changes in the behavior of Generation Z, especially students in addressing the socio-economic aspects that changed after the COVID-19 pandemic. Generation $\mathrm{Z}$ is a generation born in the span of 1995-2010. This generation is very close to the digital world and the internet so it is known as digital savvy. Generation $\mathrm{Z}$ spends time interacting and communicating on social media, so they like to create and consume content digitally. They like freedom, have a broad mindset, are impulsive and are more results oriented than process (Widiyarti, 2019). At present the majority of students in Indonesia belong to Generation $\mathrm{Z}$ based on the age range of that generation.

The discussion will be conducted through the context of consumer behavior using the black box model to explore the causes of changes in consumer behavior, both internally and externally among Generation $\mathrm{Z}$ in addressing the phenomena before and after quarantine carried out after the spread of COVID-19 in Indonesia. 
The study will discuss the views and perceptions of students as representations of the existing Generation $\mathrm{Z}$ in the face of the COVID-19 pandemic, as well as changes in the way they spend in various aspects, both before and after the COVID19 pandemic.

\section{LITERATURE REVIEW}

\section{Consumer Behavior}

The study of consumer behavior has been discussed in mapping the right marketing strategy by understanding various aspects of consumers, both in microeconomic theory, psychology, sociology, and anthropology. Consumer behavior is defined as the behavior displayed by consumers in the process of searching, buying, using, evaluating, and consuming the products and services they expect to meet their needs and desires (Hawkins \& Mothersbaugh, 2009). Consumer behavior is a complex science study because it deals with external and internal conditions of the consumer itself (Solomon, 2013).

In consumer behavior, there are several models developed by experts in mapping how consumers behave in purchasing decision process. The developed model includes the Howard - Sheth model which contains four main elements, such as stimuli or stimuli, the arrangement of hypotheses, responses (outputs), and exogenous variables (Priansa, 2017). The Engel, Kollat, and Blackwell model discusses five stages in the decision making process, starting from the problem recognition stage, the stage of information retrieval, the alternative evaluation stage, the power of purchase intention, to other external influences, such as prevailing cultural norms and values (Wright, 2006).

Kotler and Armstrong's model studies consumer behavior in developing appropriate marketing strategies for companies with the black box model to understanding consumer characteristics and consumer decision processes originating from the consumer's internal self (Kotler \& Armstrong, 2014).

\section{Black Box Model}

Black box model is an approach to consumer behavior developed by Kotler and Armstrong (2014) to understand various aspects of consumers. In the black box, it begins with marketing and other stimuli originating from external consumers, namely the 4P marketing mix, namely product, price, place, and promotion, then supported by other stimuli originating from the environment, such as the economic, technological, political, and culture.

The combination of $4 \mathrm{P}$ in the marketing mix and other stimuli that arise in the consumer is

Table 1. Buyer' Black Box Model

\begin{tabular}{lll}
\hline Stimuli $\rightarrow$ & Transformer $\rightarrow$ & Responses \\
\hline Marketing Stimuli & Buyers Characteristics & Buyer response \\
\hline - Product & - Cultural & - Product choice \\
\hline - Price & - Social & - Brand choice \\
\hline - Place & - Personal & - Retail choice \\
\hline - Promotion & - Psychological & - Dealer choice \\
\hline & & - Purchase timing \\
\hline Environmental Stimuli & Buyers Decision Making & - Purchase amount \\
\hline - Economical & 1. Problem recognition & - Purchase frequency \\
\hline - Technological & 2. Information Search & \\
\hline - Political & 3. Evaluation of alternatives & \\
\hline - Cultural & 4. Purchase decision & \\
\hline - Demographic & 5. Post purchase behavior & \\
\hline - Natural & & \\
\hline Source: Kotler \& Armstrong (2008) &
\end{tabular}


transformed into a set of responses by consumers, namely the influence internally and the decision making process. In the internal influence, consumers will consider aspects of beliefs, attitudes, values, learning processes, motives, needs, perceptions, and lifestyles. While in the decision making process, consumers will consider problem solving, information search, alternative evaluation, purchase, post purchase, and evaluation.

This process ends with a response that is indicated by product choices, brand choices, supplier choices, time of purchase, and number of purchases or not even making a purchase. Through the process of consumer behavior models developed by Kotler and Armstrong, researcher will find out how the black box in Generation Z responds to the COVID-19 pandemic phenomenon to the purchase decision process.

\section{RESEARCH METHOD}

In assessing the socio-economic impact caused by Generation Z, researcher used mixed methods in this study. Mixed methods are used to obtain more comprehensive, valid, reliable, and objective data. The model of mixed methods used is the concurrent model, through the type of concurrent triangulation strategy, in which researcher use quantitative and qualitative methods together, both in data collection and analysis (Sugiyono, 2016).

The sample in this study amounted to 186 people with the age range of Generation Z, i.e. between the ages of 17-24 years.

\section{RESULT AND DISCUSSION}

The profile of respondents can be seen in Table 2 as follows.

The COVID-19 pandemic has changed the patterns of student behavior in various ways, ranging from consumption patterns, entertainment, and spending on basic needs. Students who originally liked to eat outside the home, such as malls, food court, and culinary places (46.77\%) now turn to their own cooking consumption patterns at home $(82.80 \%)$. It is undeniable that this change in behavior is caused by students' concerns about COVID-19 transmission through processed food, so that hygiene and health factors affect student consumption patterns. Interestingly, some students said that cooking activity became one of the new hobbies developed during the COVID-19 pandemic.

Table 2. Respondents' Demographic

\begin{tabular}{|c|c|c|c|}
\hline No & Description & $\begin{array}{l}\text { Amount } \\
\text { (Person) }\end{array}$ & $\begin{array}{c}\text { Percentage } \\
(\%)\end{array}$ \\
\hline \multirow[t]{3}{*}{1} & Sex & & \\
\hline & a. Male & 102 & $54.84 \%$ \\
\hline & b. Female & 84 & $45.16 \%$ \\
\hline \multirow[t]{6}{*}{2} & Housing in Bandung & & \\
\hline & a. House with parents & 104 & $55.91 \%$ \\
\hline & b. Relatives's house & 9 & $4.84 \%$ \\
\hline & c. Apartments & 7 & $3.76 \%$ \\
\hline & d. Boarding's Room & 64 & $34.41 \%$ \\
\hline & e. Rent a House & 2 & $1.08 \%$ \\
\hline \multirow[t]{9}{*}{3} & Current Domicile & & \\
\hline & a. Bandung and surrounding areas & 121 & $65.05 \%$ \\
\hline & b. Jabodetabek & 32 & $17.20 \%$ \\
\hline & c. West Java & 16 & $8.60 \%$ \\
\hline & d. Central Java & 4 & $2.15 \%$ \\
\hline & e. Bali & 2 & $1.08 \%$ \\
\hline & f. Sumatra & 8 & $4.30 \%$ \\
\hline & g. Kalimantan & 2 & $1.08 \%$ \\
\hline & h. Sulawesi & 1 & $0.54 \%$ \\
\hline \multirow[t]{11}{*}{4} & Media to Monitor News & & \\
\hline & a. Television & 38 & $20,43 \%$ \\
\hline & b. Twitter & 22 & $11,83 \%$ \\
\hline & c. Instagram & 40 & $21,51 \%$ \\
\hline & d. WhatsApp & 2 & $1,08 \%$ \\
\hline & e. LINE & 62 & $33,33 \%$ \\
\hline & f. Facebook & 4 & $2,15 \%$ \\
\hline & g. Newspaper & 6 & $3,22 \%$ \\
\hline & h. Radio & 0 & $0 \%$ \\
\hline & i. News website & 10 & $5,37 \%$ \\
\hline & j. YouTube & 2 & $1,08 \%$ \\
\hline
\end{tabular}

Source: obtained from primary data

In terms of entertainment, students who originally enjoyed spending time in cafes/culinary places/ coffee shops $(37.63 \%)$ and hanging out with friends $(36.56 \%)$, now spend more time doing entertainment activities, be it watching online 
videos, TV, playing games in the house/boarding house (94.09\%). This change was seen as a result of the implementation of the Large-Scale Social Restrictions (Pembatasan Sosial Berskala Besar) that occurred in the city of Bandung, making a number of entertainment venues to cease operations. In addition, protection from parents and growing concerns about the spread of the COVID-19 virus make students prefer to remain at home.

In contrast to consumption and entertainment patterns, surprisingly the pattern of shopping for basic needs has not changed much. Shopping as necessary remains a shopping pattern undertaken by students during the COVID-19 pandemic. In numbers, spending patterns rose from $65.59 \%$ to $70.43 \%$. This is in contrast to the news in the media that reports the occurrence of panic buying in supermarkets since the COVID19 pandemic entered Indonesia. Students see shopping as needed and ensure that the availability of food is still available for those who need to be the focus in the necessary shopping actions.

The amount of student spending during the COVID-19 pandemic also changed from the range of $\operatorname{Rp~} 100,000.00$ - Rp 250,000.00 (60.75\%) to less than $\operatorname{Rp} 100,000.00$ (41.40\%) and in the range of $\operatorname{Rp} 250,000.00$ - Rp 500,000 00 (16.67\%). In contrast, these results provide two different perspectives from students who live in the city of Bandung and live in a boarding/apartment. Policies for Study from Home (SFH) make students save on transportation costs, reduce consumption expenses, and saving for various tasks (photocopying, printing, binding) for students in the city of Bandung.

But on the contrary for students who live in boarding/apartments because they come from out of town, weekly expenses actually increase because of the need for internet access, consumption which becomes expensive because many food stalls are closed, and various needs that could be easily obtained around the campus, but now requires a special effort to get it because many businesses are closed.

Through the black box model, study tries to understand changes in student behavior patterns in 3 stages, namely (1) stimuli, (2) transformers, and (3) responses. The three stages in the black box model contribute to changing patterns of consumption, entertainment, and spending on basic needs of students in the COVID-19 pandemic.

The discussion will be divided into 2 phases, namely before and after the COVID-19 pandemic to understand changes in consumer behavior influenced by the black box model.

\section{Student Behavior Before the Pandemic COVID-} 19

Before the COVID-19 pandemic, students preferred communal consumption of products, both in terms of food and entertainment. No wonder the variety of culinary business that is able to provide comfort for the gathering atmosphere becomes a favorite place for students. Supporting facilities, such as Wi-Fi, electric plugs, comfortable benches, and Instagrammable decoration are important considerations in the purchase decision process. The desire to display one's existence, and to be the most updated, supports the selection of brands to make purchases. Brands that are able to represent the image of Generation $\mathrm{Z}$ who are students will get the main consideration in the mind of students.

Something that is unique, viral, interesting, and offers different values will be what students look for and try. The encouragement of peer groups, social groups, and friendships will have implications for brand selection, so business people must be able to provide a strong image in representing the personality of potential customers desired in terms of decoration, facilities, and products offered. Price is not an indicator that is too dominant to influence as long as it can be balanced with the fulfillment of student needs to be recognized (esteem needs). Building experience is an essential thing that businesses must pay attention to. 
Table 3. Behavioral Patterns

\begin{tabular}{|c|c|c|c|c|}
\hline \multirow{2}{*}{ No } & \multirow{2}{*}{ Description } & \multicolumn{2}{|c|}{ Description } & \multirow{2}{*}{ Difference } \\
\hline & & Before & After & \\
\hline \multirow[t]{5}{*}{1} & Consumptions Pattern & & & \\
\hline & a. Bring meal from home & $18(9,68 \%)$ & $15(8,06 \%)$ & $-3(-1,62 \%)$ \\
\hline & b. Cook at home & $38(20,43 \%)$ & $154(82,80 \%)$ & $116(+62,37 \%)$ \\
\hline & c. Eat outside, such as malls, food court, culinary places & $87(46,77 \%)$ & $1(0,54 \%)$ & $-86(-46,23 \%)$ \\
\hline & d. Buy food through online application services (GoFood/GrabFood) & $43(23,12 \%)$ & $16(8,60 \%)$ & $-27(-14,52 \%)$ \\
\hline \multirow[t]{6}{*}{2} & Leisure Pattern & & & \\
\hline & a. Go to the mall or shopping center & $21(11,29 \%)$ & $0(0 \%)$ & $-21(-11,29 \%)$ \\
\hline & b. Watching movie at the cinema & $10(5,38 \%)$ & $0(0 \%)$ & $-10(-5,38 \%)$ \\
\hline & c. Hang out at the cafe/culinary place/coffee place & $70(37,63 \%)$ & $1(0,54 \%)$ & $-69(-37,09 \%)$ \\
\hline & d. Watch TV/play at home/boarding's room/apartment & $17(9,14 \%)$ & $175(94,09 \%)$ & $158(+84,95 \%)$ \\
\hline & e. Gather with friends & $68(36,56 \%)$ & $10(5,37 \%)$ & $-58(-31,19 \%)$ \\
\hline \multirow[t]{5}{*}{3} & Shopping Pattern & & & \\
\hline & a. Buy as necessary & $122(65,59 \%)$ & $131(70,43 \%)$ & $9(+4,84 \%)$ \\
\hline & b. Bought up at once for a certain period & $19(10,22 \%)$ & $50(26,88 \%)$ & $31(+16,66 \%)$ \\
\hline & c. Buy if there are promotions/discounts & $10(5,38 \%)$ & $1(0,54 \%)$ & $-9(-4,84 \%)$ \\
\hline & d. Buy without planning (accidentally stopped by) & $35(18,81 \%)$ & $4(2,15 \%)$ & $-31(-16,66 \%)$ \\
\hline \multirow[t]{7}{*}{4} & Expenses in a week & & & \\
\hline & a. $<100.000$ & $19(10,22 \%)$ & $77(41,40 \%)$ & $58(+31,18 \%)$ \\
\hline & b. $100.000-250.000$ & $113(60,75 \%)$ & $47(25,27 \%)$ & $-66(-35,48 \%)$ \\
\hline & c. $250.000-500.000$ & $0(0 \%)$ & $31(16,67 \%)$ & $31(+16,67 \%)$ \\
\hline & d. $500.000-1.000 .000$ & $34(18,27 \%)$ & $14(7,53 \%)$ & $-20(-10,74 \%)$ \\
\hline & e. $1.000 .000-1.500 .000$ & $10(5,38 \%)$ & $6(3,23 \%)$ & $-4(-2,15 \%)$ \\
\hline & f. $>1.500 .000$ & $10(5,38 \%)$ & $11(5,90 \%)$ & $1(+0,52 \%)$ \\
\hline
\end{tabular}

Source: obtained from primary data

Student Behavior After the Pandemic COVID-19 After the COVID-19 pandemic an adjustment in consumer behavior was affected by regulatory and environmental aspects. Psychologically, the health threat from the COVID-19 virus that spreads through droplets makes students quite worried about the rapid transmission of the virus. Finally, consumption patterns change from experience to safety and health. The pattern of shopping from the original enjoying meals in the place turned into cooking at home. This is influenced by 3 aspects, namely (1) parents, (2) media, and (3) psychological conditions. Students choose to give more effort, either waiting for parents to cook or cook their own food for safety and health. Brand selection is no longer based on the image of the experience they offer, but rather a guarantee of quality and hygiene.

This has socioeconomic implications for business people in the COVID-19 pandemic, where businesses must adapt to changes in consumer behavior, both in terms of marketing stimuli and environmental stimuli to influence the black box model of buyers in the product selection process. Research shows that health issues are a central issue that is prioritized by students, so businesses must ensure that health is an important value highlighted in the process of offering products / services. This can be demonstrated through marketing campaigns that emphasize product hygiene and safety before reaching consumers.

Given the economic conditions of the community, especially parents of students affected by the COVID-19 pandemic with layoffs or reduced income, business people must be able to present quality products/services with values that are felt affordable by students. Affordable here 
means that the quality obtained is commensurate or more with the price paid. The use of cross selling or bundling strategies can be done to provide added value for students to present an affordable price nuance.

Place is now a dimension that is no longer physically counted, but can also be accessed digitally. Large-scale social restrictions force businesses to go digital, so sales will inevitably have to penetrate cyberspace. Sales through ecommerce platforms, online motorcycle taxis and social media became "new places" to peddle merchandise until the COVID-19 pandemic was declared complete. This digital sales must be equipped with trust, reliability and speed.

Environmentally, people's behavior patterns are influenced by the media, so it is very important for business people to pay attention to the dynamics of reporting in the media. In addition, government regulations that are updated regularly need to be considered in order to ensure that business people do not merely pay attention to the profit aspect, but rather have a concern for consumers. The publication of the application of social distancing, \#DiamdiRumah, and showing empathy will provide a good image for consumers in times of crisis.

The patterns of consumer behavior that are native to Bandung have differences with students from outside the city or island. The level of independence of students living in boarding/apartments will have implications for consumption patterns, namely food shopping patterns and entertainment patterns that shift from communal experience to individuality. Consumer personality will have implications for the amount of spending according to lifestyle, on the other hand the internet is a primary need in Study from Home ( $\mathrm{SFH}$ ) which has financial consequences.

Meanwhile, students who live in Bandung experience changes in shopping and entertainment behavior patterns in terms of spending which are significantly reduced in terms of transportation, consumption, and lifestyle. Parental control, as well as psychological conditions affect product consumption. The house was transformed into a restaurant, entertainment place, mall, and campus with a catalyst in the form of the internet. Seeing the intense use of media on the LINE and Instagram platforms, business people can see this potential for marketing their products wisely.

Changes in consumer behavior among Generation $\mathrm{Z}$ has implications for 5 basic aspects in determining the focus of students when purchasing or consuming products, namely (1) orientation; (2) categories of needs; (3) shopping patterns; (4) request for service time; (5) price. The brand that is able to accommodate the shift in behavior from students is believed to be able to be the brand of choice in the COVID-19 pandemic.

\section{CONCLUSION}

The COVID-19 pandemic has changed various aspects of life, both health and economically. This also has implications for changes in consumer behavior, in this case students as Generation $\mathrm{Z}$ representations who also change behavior in various aspects, both in terms of consumption patterns, entertainment, and shopping for daily needs. Through the black box model, this

Table 4. Changes in Student Behavior in the Period Before and After the Pandemic CoVID-19

\begin{tabular}{lcc}
\hline Aspect & Before COVID-19 & After COVID-19 \\
\hline 1. Orientation & Experience & Healthy \\
\hline 2. Categories of Needs & Esteem Needs & Basic Needs \\
\hline 3. Shopping Patterns & Mostly Offline & Mostly Online \\
\hline 4. Request for Service Time & Slow & Fast \\
\hline 5. Price & Value for experience & Value for money \\
\hline
\end{tabular}

Source: author's analysis and interpretation 
research underlines 2 important things. First is the change in consumer behavior from before and after the COVID-19 pandemic. Second is the role of stimuli for the brand in providing added value to consumers during the pandemic.

This research contributes in 3 ways, namely (1) changes in consumer behavior as a result of the COVID-19 pandemic is an opportunity for businesses to start penetrating the digital market; (2) the emphasis on the importance of health is the main value that must be managed by business people during the COVID-19 pandemic; (3) businesses must begin to ensure that the business model that runs is flexible in accordance with changing conditions by regularly monitoring changes in consumer behavior.

Digital marketing referred to here is not only moving the sale of products or services to the internet, but also reading and adjusting the lifestyle of a digital society that has different characteristics compared to consumers who come directly on the spot. In addition, health issues are a major concern that businesses need to prioritize, ranging from hygiene, cleanliness, and implementation of health protocols that must be regularly disseminated to consumers, both in the form of content to consistent direct application in the field. The application of a flexible business model means that there is agility and resilient in reading market trends or opportunities that are or will be of interest to the public, namely changing some of the old business models that experienced a decline during the COVID-19 pandemic with a new business model that takes into account the situation and business ecosystem that is developing, so that the product or service being sold remains relevant.

The research is limited to the study of changes in consumption patterns, entertainment, and shopping for daily necessities for students in the Bandung area, both native citizens and migrants from out of town and island. Further research can examine other aspects that have not been analyzed in this study, such as the emergence of new trends, the role of social media, and changes in consumer behavior after the COVID-19 pandemic. In addition, expanding the scale of research in several cities or countries can be done to understand the cultural context differences in socio-economic changes.

\section{REFEREN CES}

Al-Lamongani, S. (2020, April 19). Sosiovirologi: Gambaran Perubahan Sosial Masyarakat Akibat Covid-19. Diambil kembali dari TIMES Indonesia: https://www.timesindonesia.co.id/read/news/ 266185 sosiovirologi-gambaran-perubahan-sosial-masyarakat-akibat-covid19

BBC Indonesia. (2020, March 18). Virus corona: Tak semua pengajar, siswa siap terapkan 'sekolah di rumah'. Diambil kembali dari BBC Indonesia: https://www.bbc.com/indonesia/indonesia51906763

BBC Indonesia. (2020, March 5). Virus corona: Takut jabat tangan, 'Wuhan shake' jadi pilihan. Diambil kembali dari BBC Indonesia: https://www.bbc.com/indonesia/media-51750632

CNN Indonesia. (2020, March 22). Alasan Psikologi di Balik 'Panic Buying'. Diambil kembali dari CNN Indonesia: https://www.cnnindonesia.com/gaya-hidup/20200322161747-284-485813/alasanpsikologi-di-balik-panic-buying

CNN Indonesia. (2020, April 13). Corona, Total 1,6 Juta Pekerja Kena PHK dan Dirumahkan. Diambil kembali dari CNN Indonesia: https://www.cnnindonesia.com/ekonomi/20200413130936-92493002/corona-total-16-juta-pekerja-kena-phk-dan-dirumahkan 
Detikcom. (2020, March 28). Daftar Negara yang Lockdown karena Corona. Diambil kembali dari Detikcom: https://news.detik.com/berita/d-4956298/daftar-negara-yang-lockdown-karena-corona/1

Hawkins, D., \& Mothersbaugh, D. (2009). Consumer behavior: Building marketing strategy. New York: McGraw-Hill.

Helabumi, R. (2020, April 12). Pusat Perbelanjaan Sementara Berhenti Beroperasi. Diambil kembali dari Kompas.id: https://kompas.id/baca/foto/2020/04/12/pusat-perbelanjaan-sementara-berhentiberoperasi/

Kasih, A. P. (2020, March 27). Belajar di Rumah Diperpanjang, Kemendikbud: Berikan Materi "Life Skill" dan Karakter. Diambil kembali dari Kompas.com: https://edukasi.kompas.com/read/2020/03/27/142507671/belajar-di-rumah-diperpanjangkemendikbud-berikan-materi-life-skill-dan?page=all

Kementrian PUPR. (2020, April 3). Perilaku Hidup Bersih dan Sehat (PHBS) sebagai Upaya Mencegah Penyebaran COVID-19. Diambil kembali dari Kementrian PUPR: http://plpbm.pu.go.id/v2/posts/ Perilaku-Hidup-Bersih-dan-Sehat-PHBS-sebagai-Upaya-Mencegah-Penyebaran-COVID-19

Kotler, P., \& Armstrong, G. (2008). Principles of Marketing 12th ed. New Jersey: Prentice Hall.

Kotler, P., \& Armstrong, G. (2014). Principle Of Marketing, 15th edition. New Jersey: Pearson Prentice Hal.

Mashabi, S. (2020, April 20). Daftar 18 Daerah yang Terapkan PSBB, dari Jakarta hingga Makassar. Diambil kembali dari Kompas.com: https://nasional.kompas.com/read/2020/04/20/05534481/ daftar-18-daerah-yang-terapkan-psbb-dari-jakarta-hingga-makassar

Prasetya, A. D. (2020, March 30). 5 'Challenge' Instagram Anti Mati Gaya saat \#DiRumahAja. Diambil kembali dari MerahPutih: https://merahputih.com/post/read/5-challenge-instagram-anti-matigaya-saat-dirumahaja

Priansa, D. J. (2017). Komunikasi Pemasaran Terpadu. Bandung: CV Pustaka Setia.

Putri, C. A. (2020, March 20). Peritel Blak-Blakan Ada 3 Kali Panic Buying Gegara Corona. Diambil kembali dari CNBC Indonesia: https://www.cnbcindonesia.com/news/20200320104453-4-146366/ peritel-blak-blakan-ada-3-kali-panic-buying-gegara-corona

Solomon, M. R. (2013). Consumer behavior: Buying, having, and being (10th ed.). Essex: Pearson Education. Sugiyono. (2016). Metode Penelitian Kombinasi (Mixed Methods). Bandung: CV. Alfabeta.

Widiyarti, Y. (2019, January 6). Mengenal Karakter Generasi Z, Mandiri, Keras Kepala tapi Inovatif. Diambil kembali dari Tempo.co: https://cantik.tempo.co/read/1162188/mengenal-karakter-generasi-zmandiri-keras-kepala-tapi-inovatif/full\&view $=$ ok

WorldoMeter. (2020, April 20). COVID-19 Coronavirus Pandemic. Diambil kembali dari WorldoMeter: https://www.worldometers.info/coronavirus/

Wright, R. (2006). Consumer behaviour. London: Thomson Learning. 